\title{
Analyzing the production-distribution-consumption cycle using hierarchical modeling methods
}

\section{Venera Timiryanova ${ }^{a^{*}}$}

\begin{tabular}{|c|c|}
\hline C H R O N I C L E & A B S T R A C T \\
\hline $\begin{array}{l}\text { Article history: } \\
\text { Received: April 29, } 2020 \\
\text { Received in revised format: } \\
\text { July } 302020 \\
\text { Accepted: August 10, } 2020 \\
\text { Available online: } \\
\text { August } 17,2020 \\
\text { Keywords: } \\
\text { Production-distribution- } \\
\text { consumption cycle } \\
\text { Hierarchical linear model } \\
\text { Central place hierarchies }\end{array}$ & $\begin{array}{l}\text { The production-distribution-consumption cycle is one of the main cycles on which the economy state } \\
\text { depends on. This study aims to determine the relationship between production, distribution, and } \\
\text { consumption of goods within the central place hierarchies using hierarchical modeling (HLM). It } \\
\text { allows us to analyze indicators within several levels of data aggregation. The analysis is carried out } \\
\text { in the context of } 2319 \text { municipalities that are part of } 84 \text { regions of the Russian Federation, in } 8 \text { federal } \\
\text { districts. The results show that hierarchical analysis methods can be used in the production- } \\
\text { distribution-consumption cycle study. As part of the model's results, it was noted that the income of } \\
\text { the population and exports, which determine the demands for goods, have a positive impact on the } \\
\text { production and sales of goods. At the same time, the relationship between production and wholesale } \\
\text { trade, which characterizes the distribution of goods, is not so clear. The production-distribution- } \\
\text { consumption cycle study considers the hierarchy of central places, which takes into account the } \\
\text { division of the territory into zones based on the functions performed. The methods of hierarchical } \\
\text { analysis made it possible to evaluate the effects generated at each level. We managed to take into } \\
\text { account the spatial heterogeneity and hierarchical structure of the data describing the production- } \\
\text { distribution-consumption cycle. This will improve the quality of decisions when determining the } \\
\text { manufacturing locations, as well as providing a better approach to the development of territories by } \\
\text { state authorities. }\end{array}$ \\
\hline
\end{tabular}

(C) 2021 by the authors; licensee Growing Science, Canada

\section{Introduction}

Matters attributed to the location of manufacturing, industrial location, distribution centers and retail location relative to consumers of goods have been raised many times (Ketokivi et al., 2017, Webber, 2020; Quynh et al., 2020; Ge et al., 2019, Öner, 2016). The interest in them is large because production and consumption do not occur at the same time or the same geographical point. In most cases, there is some gap in time and space between the production and consumption of goods. For example, the production of certain goods is often impossible to be close to the buyer as it requires special production conditions. Some products are in demand from a small number of buyers located in different parts of the world and commencement of proceedings near each of them is economically unfeasible. Some commodities such as vegetables and fruits that are collected during a certain period need special storage until they are consumed. The gap between production and consumption is bridged by wholesale and retail businesses. The decision about their location is influenced by many factors, including the economic attractiveness of the territory, organizational and technological conditions. The lack of goods is often compensated by their imports from other countries while transport conditions are an important factor in determining import channels. Often the placement of production and marketing enterprises is considered in a complex. For instance, the location of the supply chain is analyzed concerning placing on production and consumers simultaneously $(\mathrm{Ge}, 2019)$ while manufacturing enterprises in terms

* Corresponding author

E-mail address: veneratimiryanova@mail.ru (V. Timiryanova) 
of component suppliers and market outlets (Ketokivi et al., 2017). Webber (2020) points out that "the location of the industry reflects the economic character of society". Moreover, a well-organized system of industrial and traders creates more comfortable living conditions for the population. Therefore, researches on the optimal, ideal business location are still actively conducted. Determining whether the business location is successful in a complex is possible only if we consider production, distribution, import, and consumption as a single mechanism for ensuring the movement of goods. However, the problem arising in integrated treatment is related to different territorial coverage of these activity types. The import of goods usually involves the delivery of goods in large quantities to provide goods for part or all of the country. As a rule, wholesale trade covers several districts, and product promotion implies inter district interaction. In turn, the sales volumes of goods within particular territories are determined by the demand forming by the territory's population. Here the analysis can be narrowed to the town areas. This nesting of processes is well described in the framework of the theory of central place hierarchies and areal functional organization (Berry \& Garrison, 1958; Borchert \& Adams, 1963; Fox \& Krishna, 1965, King, 2020). These concepts treat farm and home as the smallest units of the area of a human organization in the world economy where it is possible to identify somefold nested hierarchy of functions (Philbrick, 2005).

This paper aims to determine the relationship among production, distribution, import, and demand for goods within the central place hierarchies using hierarchical modeling methods. In this research the production-distribution-consumption cycle is viewed as a hierarchically structured process. Hierarchical analysis methods allow to distribute the effects generated at different levels of the areal functional organization, and analyze the location of production and trade enterprises in a new way.

\section{Literature Review}

The interrelationship between production, distribution, and consumption has been studied for a long time. However, scientists take different approaches to this issue. Many studies are conducted to investigate the proportions in which production and consumption are related (Sonis et al., 1995; Liu, Hewings, 2019; Leontief, 1963). As part of the input-output tables, scientists are trying to integrate the interregional and intersectoral interdependencies (Sonis et al., 1995). They mentioned that geographic space is discrete and quantitative methods may be used easily in either one- or two-dimensional space (Fan, Treyz, 2020). But in these studies, scientists are primarily interested in the feedback loop, which means a series of transactions, in which each sector of the economy appears only once with one incoming flow and one outgoing flow (Liu \& Hewings, 2019). At the same time, in the framework of regional studies, there is a pivotal inference of scientists that the structure of nested feedback loop hierarchies could be extracted for the general case of an n-region/m-sector input-output system (Sonis et al., 1995). Other authors focus on production location, distribution, and consumption. For instance, Lösch (2007) managed to build up in logical sequence a system of market regions, showing the territorial organization of consumption and production. This idea was evolved by many scientists (Berry \& Garrison, 1995; Borchert \& Adams, 1963; Fox \& Krishna, 1965, King, 2020; Nystuen \& Dacey, 1961; Philbrick, 2005). In their works, authors tried to structure this system, determine the criteria on which centers of different levels can be identified. The allocation of levels was carried out by them based on the functions performed by these centers. As King (King, 2020) notes, "the list of these functions has approached one hundred or so". In some studies, the emphasis was on the relationship between production, distribution, and consumption. Philbrick (2005) showed that the first three of seven orders of areal units of the organization is a consumer (establishment, a group of parcels), retail (focal place, a cluster of establishments), wholesale (cluster of focal places). Borchert and Adams (1963) considered only the Trade Center hierarchy in which they identified six levels: minimum convenience centers, full convenience centers, partial shopping centers, complete shopping, secondary and primary wholesale-retail. Based on Borchert's and Adams's work, Fox and Krishna (1965) assumed that consumption theory may also be attributed to central place hierarchies within FEA (foreign economic activity). Besides, they believe that it would be possible to disaggregate the entries of a national input-output model down to the FEA basis and group the industries within each region into "export" and "residentiary" sectors depending on their functions. Thus, the possibility of combining research areas in terms of the interrelationship of production, distribution, and consumption was entrenched: inputoutput system and central place hierarchies. Both of them take into consideration the hierarchical structure of data and the nesting of processes. This makes it possible to apply hierarchical analysis methods to the production-distribution-consumption cycle research. They are based on representations of hierarchically structured spatially organized data - hierarchical spatial data (Car, 2004; Timpf, 1997). The hierarchical analysis is based on the idea of an alternative approach to capture spatial effects and focus on the multi-level aspects of cause-effect relationships that are the reality of many spatial processes (Corrado, 2011). Methods of scoring for analyzing hierarchical relationships were developed through the efforts of H. Goldstein (Goldstein, 2010) and Garson (2013). Hierarchical models are enabled to take into account spatial heterogeneity and hierarchical data structure simultaneously while identifying both lower-level effects and the spatial context determined by higher levels. This method was used by Wicht et al. (2019) investigate whether the division into economic functional regions is better than administrative regions for evaluating economic processes. However, they used unemployment and employment rates, income levels, and housing price rather than indicators characterizing production and consumption as data. At the same time, Hierarchical linear modeling (HTM) methods were used to analyze the production output, personal income, consumption, and firm reaction speed within the supply chain (Lawson et al., 2019). Although these studies are not interrelated methods of the 
hierarchical analysis showed their applicability to researches dealing with various aspects of the production-distributionconsumption cycle.

\section{The Study Problem and Question}

The nesting of territories described within central place hierarchies allows us to use hierarchical analysis methods to evaluate the production-distribution-consumption cycle. Hierarchical nesting of data is manifested at each phase of the productiondistribution-consumption cycle. Thus, the production of the goods takes place at a certain enterprise located in a municipality and finds its expression in the characteristics of its development. In its turn, the municipality is a part of the region where the region being constituent entity represents the part of the federal district. The nesting of data is evident in that the total production of enterprises of all municipalities is a characteristic of the region and the federal district, respectively. Taking into account this nesting, various factors allocated at different levels of territorial division can be considered. As a result, the following hypotheses will be tested using hierarchical analysis methods to assess the impact of certain phases in the production-distributionconsumption cycle on each other.

H1- The total population income determines the demand for manufactured goods and has a positive effect on the production volume and marketing of food products.

$\mathrm{H} 2$-Export characterizes external demand for goods produced in the local area and has a positive effect on the production volume.

H3 - The import of goods negatively affects production volume, as it being competitive relative to the latter.

H4 - The import of goods has a positive impact on the total sales volume of food products in the region (both produced and imported), as an increase in the range of imported goods enables to meet the interests of the population more widely.

H5 - Wholesale trade has a positive effect on the volume of production as its function is to promote the manufactured goods to the consumer.

H6 - Wholesale trade has a positive impact on the sales volume of food products as its function is to fill the market with goods that are in demand from the consumer.

Hypothesis testing involves the sequential construction of several models, the features of which are described below.

\section{Study Methodology}

Before proceeding to the empirical analysis, we will present the general framework and concepts used to address this issue. We will consider the location decision in two aspects:

- production and consumption are linked through the distribution, export, import, and sale of goods; - according to the theories of nodal regions and central places hierarchies in geographical time-space-direct nested the feedbacks of supply and demand can be identified.

The location of the central place is not important in the study while its area (region) is of interest. Nystuen and Dacey (1961) treat a nodal region as an aggregation of certain areas that has a dominant association with it. The nodal region examines the relationship between the hinterland which is a real as well as the central or nodal city, which is punctiform. In this study, the area boundary is defined by territorial division. In this case, we are moving away from the ideal spatial structure considered by Lösch (2007), which is primarily due to the specificity of the gathering statistical data. A similar decision was made by Öner (2016) while investigating the nesting of markets (municipal, regional, external) in the context of administrative-territorial units.

\subsection{The study variables and data}

The resulting framework allows us to examine the cases within a single framework that is general enough and does not exclude anything potentially significant. Two ways of evaluating the processes occurring in the production-distribution-consumption cycle will be considered. In the first case, our focus is on the first production stage. In this paper, by production, we mean specifically manufacturing activities. We will consider the next factors that affect production: population income, wholesale turnover, and the volume of exports and imports. The logic for including these variables is presented as follows. The product can be sold and consumed in the territory where it is produced therefore the production of goods is influenced by the demand that exists in this territory. In turn, demand largely depends on the population's income. The other goods that are not consumed can be sold in neighboring or foreign markets and wholesale trade is responsible for this process. According to the concept of central places wholesale trade is not limited by a single market, but it has an area covering several municipalities within which it organizes the movement of goods. Wholesale trade contributes to the promotion of the product outside its area and performs many other functions, such as sharing proprietary information with the business. In addition to trade, the study takes into account export and import. On the one hand, import aims at satisfying consumers. At the same time, imported goods compete with local 
goods; consequently, they affect the development of production in the territory. Export shows the possibility of selling manufactured goods outside the territory. In total, integration of data both on the localization of goods production, demand for them, and data on the volume of wholesale trade and foreign trade activities grouped within certain areas, allows us to assess how it operates in the whole within a geographically organized economic space. In the second case, the emphasis is on the sales figure of food products, thus not all imports are taken into consideration because it includes both the supply of goods for final consumption and materials for subsequent production. The model embraces only the import of goods for final consumption. The data used for analysis is described in Table 1.

\section{Table1}

Description of indicators

Indicator Characteristic $\quad$ Numberofobservations Datasource

\begin{tabular}{|c|c|c|c|}
\hline \multicolumn{3}{|c|}{ Municipalities(level 1) } & \multirow{4}{*}{$\begin{array}{l}\text { Federal state statistics service } \\
\text { (https://www.gks.ru/dbscripts } \\
\text { /munst/ }\end{array}$} \\
\hline $\begin{array}{l}\text { The volume of production } \\
\left(P_{i j k}\right)\end{array}$ & $\begin{array}{l}\text { The volume of shipped goods of own production, performed } \\
\text { works and in-house services (not including small } \\
\text { businesses) }\end{array}$ & 2132 & \\
\hline $\begin{array}{l}\text { The sales volume of food } \\
\text { products (FP) }\end{array}$ & $\begin{array}{l}\text { A total volume of all food products sold within the borders } \\
\text { of the municipality }\end{array}$ & 2319 & \\
\hline $\begin{array}{l}\text { Social transfers and } \\
\text { population's income(STPI) }\end{array}$ & $\begin{array}{l}\text { The volume of income transfers to the population and } \\
\text { taxable income }\end{array}$ & 2319 & \\
\hline Wholesale turnover (WT) & $\begin{array}{l}\text { Regions (level 2) } \\
\text { According to the methodology of the Federal state statistics } \\
\text { service, the figures include the volume of activity that is not } \\
\text { observed by direct statistical methods while taking into } \\
\text { account organizations whose wholesale trade is the main } \\
\text { type of economic activity }\end{array}$ & 84 & $\begin{array}{lr}\text { The } & \text { Unified } \\
\text { Interdepartmental } & \text { Statistical } \\
\text { Information } & \text { System } \\
\text { (https://www.fedstat.ru/) }\end{array}$ \\
\hline Total Export (E) & $\begin{array}{l}\text { The volume of products exported outside the Russian } \\
\text { Federation, including materials. }\end{array}$ & 8 & \multirow{3}{*}{$\begin{array}{l}\text { Federal customs service of the } \\
\text { Russian Federation } \\
\text { (http://stat.customs.ru/). }\end{array}$} \\
\hline Total Import (I) & $\begin{array}{l}\text { The volume of products imported to the territory of the } \\
\text { Russian Federation, including materials. }\end{array}$ & 8 & \\
\hline $\begin{array}{l}\text { Imports of consumer goods } \\
\text { (ICG) }\end{array}$ & $\begin{array}{l}\text { It includes imports of goods only for retail sales and final } \\
\text { consumption, without materials used in production. }\end{array}$ & 8 & \\
\hline
\end{tabular}

Data is not available for certain closed cities so they are excluded from the calculations. Focusing on the relationship between the production, distribution, and consumption of goods all indicators were calculated per capita that has made it possible not to take into analysis the population of the territories under consideration. Fig. 1 demonstrates two leaders located in the northwestern part of the country in terms of import and export. Different processes of import and export are taking place in the rest of federal districts. Differences are also evident in foreign trade supplies of materials and final goods. In contrast to the existing body of literature where hierarchy covers five, six, or seven levels the examined indicators are analyzed within three levels. However, this division generally suits the points of central place theory as it presupposes territorial partition into areas according to functions performed. The study was conducted based on data from 2,319 municipalities located in 84 regions of the Russian Federation, in 8 federal districts using data for 2018. (Fig. 1,2). The calculations were performed using a specialized HLM program developed by Scientific Software International Inc.

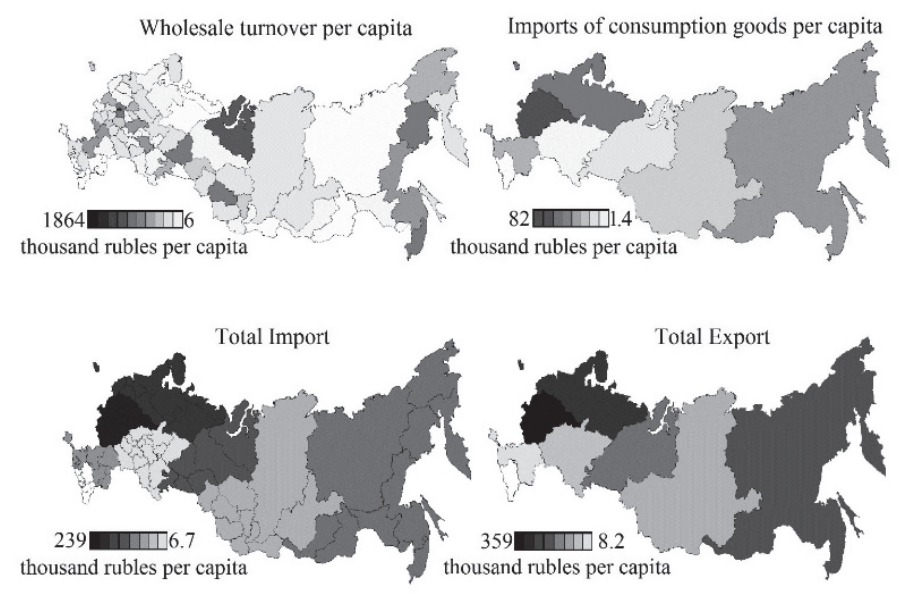

Fig. 1. Wholesale turnover, imports of consumption goods, total import and total export 
The volume of production per capita

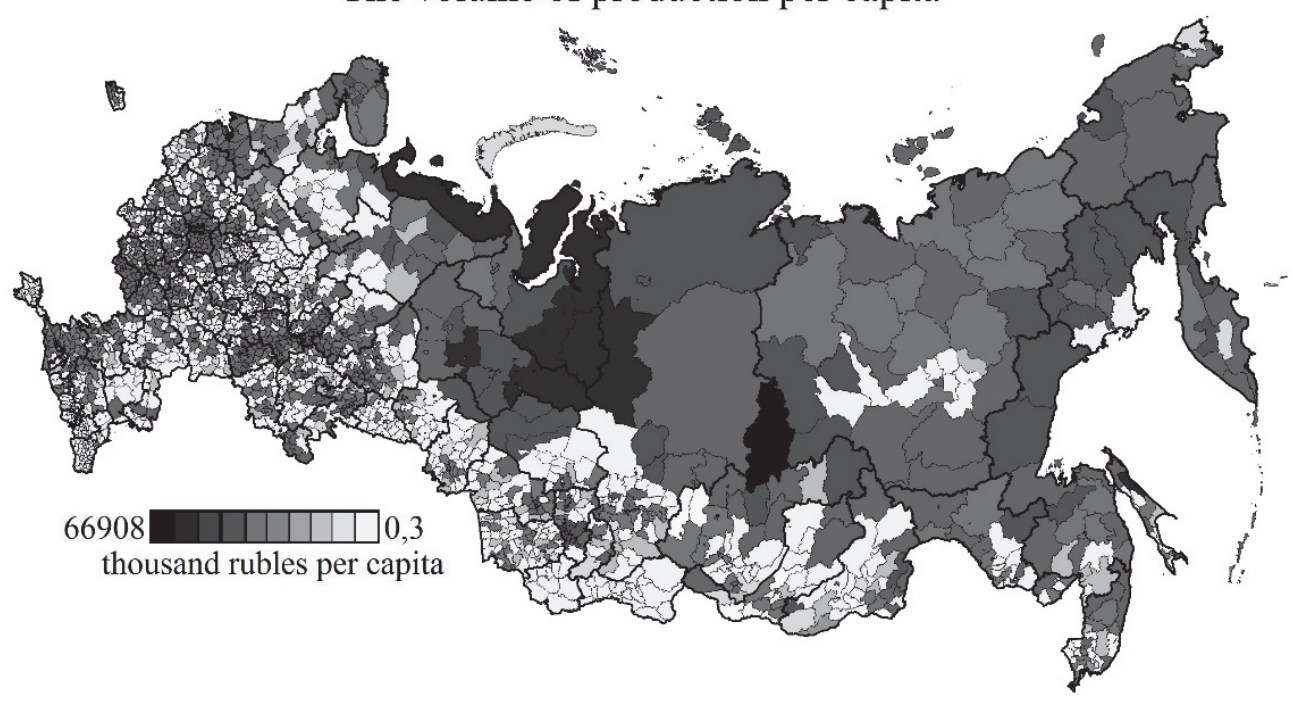

The sales volume of food products per capita

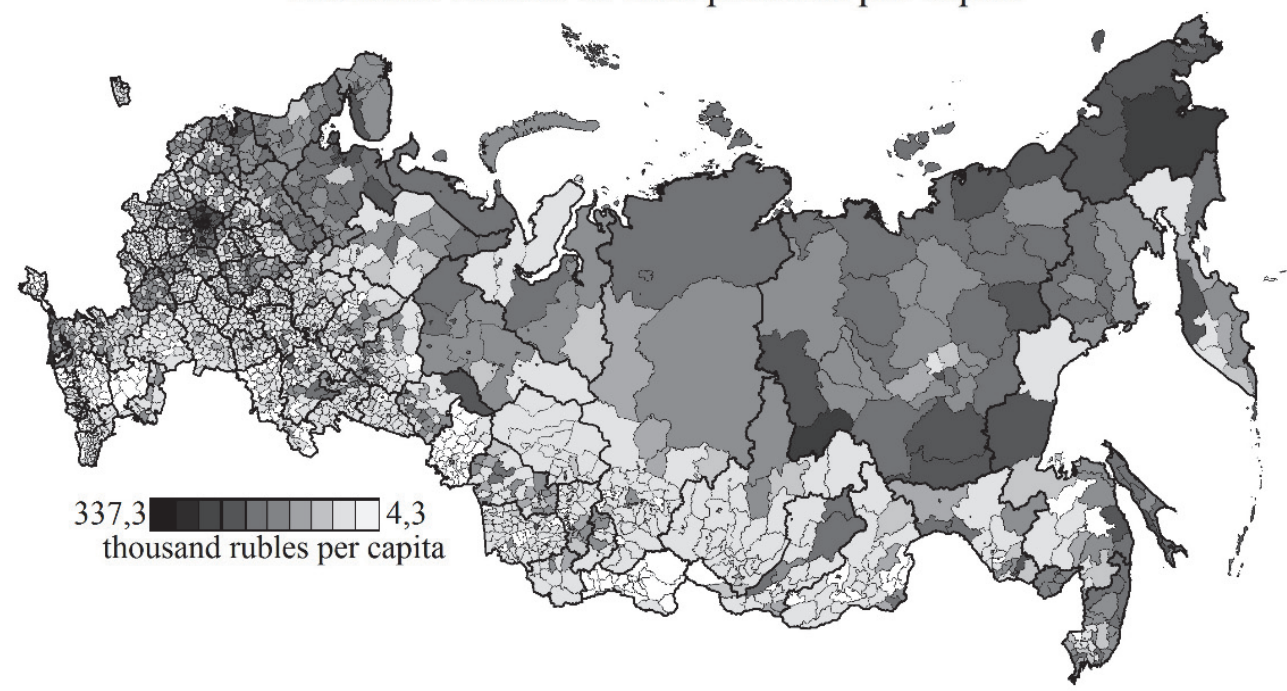

Social transfers and population's income per capita

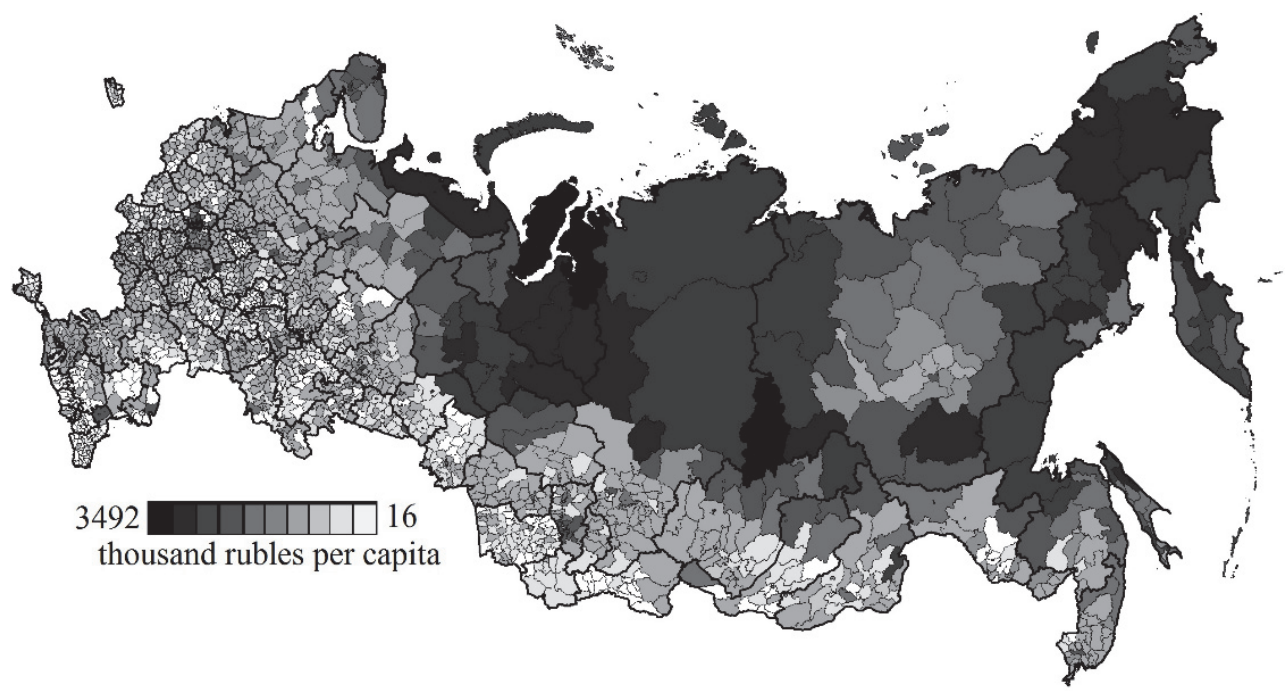

Fig. 2. The volume of production, social transfers and population's income, the sales volume of food products 
The Hierarchical linear modeling (HLM) method is used in this study. First, we will conduct an analysis without preconditions, examining how much variance concentrates within the municipalities, regions, and federal districts. We will model this on three levels, with the within-cell model detailing the variation among the municipality nested in the region which is nested in the federal district. Based on the variation data, the intraclass correlation coefficient (ICC) can be estimated:

$$
I C C=\frac{\sigma_{j}^{2}}{\sigma_{k}^{2}+\sigma_{i}^{2}+\sigma_{j}^{2}},
$$

where $\sigma_{\mathrm{i}}, \sigma_{\mathrm{j}}$, and $\sigma_{\mathrm{k}}$ - intra-group variance at the level of municipalities, regions, and federal districts. This equation represents the ratio of region variance to the total variance. The coefficient value varies from +1 , where a variance is determined directly by the difference between groups if there is no variance within groups, to $\frac{1}{(n-1)}$, where the variance is mainly intra-group (where $\mathrm{n}$ - number of municipalities). The coefficient value close to zero shows that the high level of the management hierarchy does not affect the development of municipalities. If the ICC is less than $5 \%$, then the analysis of grouped data becomes useless (Bliese, 2000). Next, we enroll the independent variables sequentially. First at the lower level (municipalities), then we introduce a variable that characterizes the performance of the wholesale trade function in the regions. Last thing, we include data on exports and imports at the federal district level. Thus, production, distribution, export-import of goods, and consumption are considered in the framework of two full random coefficients regression models Both models include a predictor at the municipal level that allows us to estimate how the volume of production in a municipality depends on domestic demand, determined by the population income. The first model contains the $W T_{j}$ factor at the regional level and $\mathrm{E}_{\mathrm{k}} \mathrm{U} \mathrm{I}_{\mathrm{k}}$ factors introduced at the level of the federal districts allow taking into account the influence of wholesale trade within the region, exports, and imports throughout the federal districts on the differences between municipalities, respectively (Eqs. (2-4)).

Level 1 (lower, municipalities):

Level 2 (medium, regions):

Level 3 (upper level):

$$
\begin{gathered}
P_{i j k}=\alpha_{0 j k}+\alpha_{1 j k} \cdot S T P I_{i j k}+\varepsilon_{i j k} \\
\alpha_{0 j k}=\beta_{00 k}+\beta_{01 k} \cdot W T_{j k}+r_{0 j k} \\
\beta_{00 k}=\gamma_{000}+\gamma_{001} \cdot E_{k}+\gamma_{002} \cdot I_{k}+u_{00 k}
\end{gathered}
$$

where $P_{i j k}$-the volume of production per capita in the i-th municipality of the j-th region of the Russian Federation, the k-th federal district, thousand rubles/per capita;

$S T P I_{i j k}$ - social transfers and population's income per capita in the i-th municipality of the j-th region of the Russian Federation, the k-th federal district, thousand rubles/per capita;

$W T_{j k}$ - the wholesale turnover per capita in the i-th municipality of the j-th region of the Russian Federation, the k-th federal district, thousand rubles/per capita;

$E_{k}$ - total exports per capita of the k-th federal district, thousand rubles/per capita;

$I_{k}$ - total imports per capita of the k-th federal district, thousand rubles/per capita;

$\gamma_{000}-$ general intercept for all municipalities;

$\alpha_{1 j k}, \beta_{01 k}, \gamma_{001}, \gamma_{002}$ - regression coefficients (slopes);

$\varepsilon_{i j k}$ - error of intraregional variance (intermunicipal) describing differences between municipalities within certain regions;

$r_{0 j k}$ - error of interregional variance explaining differences between region values of indices achieved by their constituent municipalities;

$u_{00 k}$ - error of variance between districts, that explains differences between federal districts values;

$\mathrm{k}$ - index for affiliation of a municipality to the federal district, $(\mathrm{j}=1,2, \ldots, 8)$;

$\mathrm{j}$ - index for affiliation of a municipality to a specific subject of the Russian Federation, $(j=1,2, \ldots, 84)$;

$\mathrm{i}$ - index for affiliation to a particular municipality $(\mathrm{i}=1,2, \ldots, 2320)$

As in the previous model, the social transfers and population's income factor (STPI) is included in to the second model. At the regional level, we enroll factor reflecting the development of distribution channels (WT). At the federal district level, only imports of goods for final sale are taken into consideration. The model tests the assumption that the sales volume of food products (FP) depends on a certain effect generated by the federal district and its participation in foreign trade operations (ICG), effect driven by the subject of the Russian Federation and development of wholesale trade (WT) at the level of the subject of the Russian Federation, the population's income (STPI) at the level of municipalities (equations 5-7).

Level 1 (lower, municipalities):

Level 2 (medium, regions):

Level 3 (upper, federal districts):

$$
\begin{gathered}
F P_{i j k}=\alpha_{0 j k}+\alpha_{1 j k} \cdot S T P I_{i j k}+\varepsilon_{i j k} \\
\alpha_{0 j k}=\beta_{00 k}+\beta_{01 k} \cdot W T_{j k}+r_{0 j k} \\
\beta_{00 k}=\gamma_{000}+\gamma_{001} \cdot I C G_{k}+u_{00 k}
\end{gathered}
$$


where $F P_{i j k^{-}}$sales volume of food products per capita in the i-th municipality of the j-th region of the Russian Federation, k-th federal district, thousand rubles/per capita.

$I C G_{k}$ - total imports of consumer goods on average per capita of the k-th federal district, thousand rubles/per capita. To determine whether a regression model with predictors is significantly more suitable than an intercept-only (null) model without predictors, the likelihood ratio test can be used. To assess improvement in model fit we investigate the residual variance component. The residual variance component is variance attributed to within-region variation in $\mathrm{P}$ that is not explained by the random effects of federal districts on the intercept of P and on the slope of STPI, WT, E and I. As the random effects explain more, the residual component will reduce.

\section{Results}

A total of eight models have been constructed. The involvement of first four models enables us to analyze the volume of output (Table 2). Initially, the null model (model 1) was built that is a basis for comparison with subsequent models. The calculated intraclass correlation coefficient showed that the variation in municipalities in terms of volume of output on $14.98 \%$ is determined by which federal district they are located in and on $23.03 \%$ by what region they are located in. This is a sizeable influence of upper-level factors on the lower level.

Table 2

Results of multivariate HLM regression analysis

\begin{tabular}{lcccc}
\hline & Model 1 & Model2 & Model3 & Model4 \\
\hline Intercept & $718.6^{* *}$ & $-2004.9^{* * *}$ & $-1619.1^{* * *}$ & $\begin{array}{c}-2349.8^{* * *} \\
(291.3)\end{array}$ \\
STPI & $(253.4)$ & $(232.3)$ & $(248.7)$ & $\begin{array}{c}10.9^{* * *} \\
(0.3)\end{array}$ \\
WT & & $10.6^{* * *}$ & $\left(0.9^{* * *}\right.$ & $\begin{array}{c}-2.3^{* * *} \\
(0.6)\end{array}$ \\
E & & $(0.3)$ & $(0.6)$ & $528.1^{* *}$ \\
& & & & $(146.3)$ \\
I & & & & $-552.9^{* *}$ \\
& & & & $(191.5)$ \\
Reliability estimate: & & & & \\
level-1 & & & & 0.663 \\
level-2 & 0.731 & 0.679 & 0.660 & 0.498 \\
Deviance & 0.732 & 0.809 & 0.813 & 38365.7 \\
The value of the log-likelihood function & 39602.5 & 38386.2 & 38372.7 & -19182.9 \\
\hline
\end{tabular}

$* \mathrm{p} \leq 0.1, * * \mathrm{p} \leq 0.05, * * * \mathrm{p} \leq 0.01$

Source: author processing

It should be noted that the reliability estimate in the latest model has decreased at both levels. At the same time, there is a reduction in deviance and the value of the log-likelihood function, which indicates that the full random coefficients regression model has more explanatory power. All factors introduced in 2-4 models are significant. Robust estimates were not taken into account due to the small number of selected groups at the top level (only 8 federal districts). A positive value for STPI and E coefficients indicates that their rising has an impact on the increase in production. It is natural because with the growth of demand, determined by the income of the local population and external markets, the need for the production of goods increases. At the same time, imported goods compete and negatively affect local production. This relationship is shown in the negative coefficient for I. Thus, the hypotheses H1, H2, H3 are confirmed. The situation with WT variable, which characterizes the distribution of goods, is rather interesting. The better the supply chain functions, the more opportunities there are for selling manufactured goods. However, as we can see, the coefficient that indicates inverse relationship is negative. Thus, the H5 hypothesis for the volume of production is rejected. It is important to note several aspects here. First, wholesale trade in Russia is more focused on the supply of goods to the market, rather than on the promotion of local products to neighboring markets. Moreover, there is a high concentration of wholesale trade. Almost $60 \%$ of goods are delivered to the regions via Moscow and the Moscow region. This situation is a consequence of the command system developed during the Soviet period, in which entire production and sales plans were formed in Moscow and in the form of directives were referred to the regions. For many years goods were transported to the center and then distributed further. As a result, significant storage areas are concentrated here. Although the situation is slowly changing it is still difficult to talk about the existence of a warehouse logistics system in the regions. Misrepresentation also occurs because the volume of the shipped goods in manufacturing includes processing of oil, the wholesale trade of which is not reflected in the wholesale trade indicator used in the calculations. The second group of models (Table 3) is more focused on studying the movement of consumer goods purchased by the population. The volume of food products sold is taken as a dependent variable. As noted above, wholesale trade is more focused on supplying customers, 
rather than promoting products from manufacturers. Models 6-8 show that the coefficient for WT is positive. Thus, for the indicator volume of food products sold, the H6 hypothesis is confirmed.

Table 3

Results of multivariate HLM regression analysis

\begin{tabular}{|c|c|c|c|c|}
\hline & Model 5 & Model6 & Model7 & Model 8 \\
\hline Intercept & $\begin{array}{c}52.7 * * * \\
(4.3)\end{array}$ & $\begin{array}{c}38.8^{* * * *} \\
(3.2)\end{array}$ & $\begin{array}{c}39.8 * * * \\
(3.5)\end{array}$ & $\begin{array}{c}35.3 * * * \\
(3.4)\end{array}$ \\
\hline STPI & & $\begin{array}{c}0.06^{* * *} \\
(0.01)\end{array}$ & $\begin{array}{c}0.05 * * * \\
(0.01)\end{array}$ & $\begin{array}{c}0.05 * * * \\
(0.01)\end{array}$ \\
\hline WT & & & $\begin{array}{l}0.02 * * \\
(0.01)\end{array}$ & $\begin{array}{l}0.02 * * \\
(0.01)\end{array}$ \\
\hline ICG & & & & $\begin{array}{c}12.7 * \\
(5.5)\end{array}$ \\
\hline $\begin{array}{l}\text { Reliabilityestimate: } \\
\text { level-1 } \\
\text { level-2 }\end{array}$ & $\begin{array}{l}0.768 \\
0.792\end{array}$ & $\begin{array}{l}0.697 \\
0.685\end{array}$ & $\begin{array}{l}0.684 \\
0.748\end{array}$ & $\begin{array}{l}0.683 \\
0.581\end{array}$ \\
\hline Deviance & 23499.3 & 23166.5 & 23162.1 & 23158.1 \\
\hline The value of the log-likelihood function & -11749.6 & -11583.2 & -11581.1 & -11579.0 \\
\hline
\end{tabular}

The calculation of the intraclass correlation coefficient in the null model (model 5) showed that the upper levels of the hierarchy territorial division significantly affect the values achieved by municipalities for such an indicator as to the volume of food products sold per capita. At the same time, the contribution on level of the federal districts is $14.3 \%$, and for the subjects of the Russian Federation is $24.1 \%$. Thus, almost $61.6 \%$ of the variation is attributed to the characteristics of municipalities and 38.41 $\%$ of it to the subject of the Russian Federation and the federal district within which they are located. After enrolling factor variables, the unexplained share on effect of the federal districts decreased to $4.5 \%$, while for the subjects of the Russian Federation it rose to $18.4 \%$. The coefficient values indicate a unidirectional change of factors and the dependent variable, thus, with an increase in the volume of wholesale trade, imports of products and income of the population, the sales volume of food products within the borders of municipalities and urban districts grow. Thus, the hypothesis $\mathrm{H} 4$ is confirmed: the import of goods has a positive impact on the total sales volume of food products in the region because the increase in the range of imported goods allows meeting the interests of the population more widely. At the same time, a relatively high constant value indicates the presence of significant unaddressed factors.

\section{Conclusion}

The conducted calculations showed that the methods of hierarchical analysis can be used to study the production-distributionconsumption cycle as they broaden existing research methods. These methods enable us to take into account both the microand macro-level factors while spreading the existing territorial variation according to the achieved values at several levels, bearing in mind the hierarchy of central places. In conditions of weak development of the database of the micro-level, the advantage of the method is that it is possible to include aggregates of the upper level in the calculations. In this case, we managed to take into consideration the flows of wholesale turnover and imports that were not defined at the municipal level, characterizing the distribution and exchange of goods. The constructed models showed that the volume of production is positively associated with exports and population income determining the domestic demand for goods. The volume of food products sold is also positively linked to the population income. At the same time, wholesale trade and import of goods have different impacts on changes in indicators. This is largely due to entrenched features of the trade flows organization. Most of the manufactured and exported goods are transported to Moscow, from where they are directed towards regions. In general, the results indicate that the current system of wholesale enterprise's placement does not allow to fully develop the functions that are imposed on them. The resulting models can be improved by introducing new explanatory factors and performing calculations in the context of product groups (category). So, for example in the work of Öner, Ö. it is noted that food retailing is known to be very dependent on the proximity of demand (Öner, 2016). At the same time, another category - clothing corresponds to a large share of the retail market; at the same time in Russia, most of the goods in this category are imported. The territorial specialization in the production of certain groups of goods is frequently referred to. Concerning Russian data, it should be noted that strong differences in climatic conditions determine the location of food products production mainly in the southern part of the country while the production of goods of the third category, involves electronic goods, furniture, and construction materials locates in the central part of the country. Taking into account the differences in the areas of sales of individual product groups, the variable that characterizes the retail turnover for each group of products can be introduced. It, in turn, can be introduce at the level of municipalities (for example, for food) and regions (clothing and electronic goods). In this study, the division of the territory was made rather based on the existing territorial division than on functional regions. This is a rather controversial decision. A study 
by Wicht et al. (2019) shows that "economic functional regions tend to better reflect spatial clustering than administrative ones. However, a significant amount of clustering at a lower aggregation level cannot be accounted for by economic functional regions, especially around metropolitan centers". Given this, the study of production-distribution-consumption cycle can be considered based on the allocation of nodal regions according their functions. The indicators were analyzed only within the framework of three levels, in contrast to the hierarchies considered in the literature which contains 5, 6, 7 levels of central places. With the development of hierarchical analysis tools, the more levels of analysis and indicators that define the functions of these levels might be embedded in the models. Despite these shortcomings, the use of hierarchical analysis methods opens up new opportunities for analyzing the production-distribution-consumption cycle. This information will be useful for businesses when choosing locations and government agencies that planning territorial development.

\section{Acknowledgement}

This work is supported by the Ministry of Science and Higher Education of the Russian Federation (scientific code FZWU2020-0027).

\section{References}

Berry, B. J., \& Garrison W. L. (1958). The functional bases of the central place hierarchy. Economic Geography, 34, 145-154

Bliese, P. D. (2000), Within-group agreement, nonindependence, and reliability: implications for data aggregation and analysis. [In:] K. J. Klein, \& S. W. J. Kozlowski (Eds.) Multi-level theory, research and methods in organizations: Foundations, extensions, and new directions. San Francisco, CA: Jossey-Bass.

Borchert J., \& Adams R. (1963). Trade Centers and Trade Areas of the Upper Midwest. Upper Midwest Economic Study. Retrieved from the University of Minnesota Digital Conservancy, http://hdl.handle.net/11299/160789.

Car, A. (1994) Modeling a Hierarchy of Space Applied to Large Road Networks. Geographic Information Systems. Proceedings of International Workshop on Advanced Research in GIS, in Ascona, Switzerland, ed. J. Nievergelt, et al. Berlin: SpringerVerlag, 15-24.

Chen, C.-K. (2012). Hierarchical linear relationship between the U.S. leisure and entertainment consumption. Technology in Society, 34(1), 44-54. doi:10.1016/j.techsoc.2011.12.003

Corrado, L. (2011) Where is the economics in spatial econometrics? Journal of Regional Science, 52(2), 210-239.

Fan, W., Treyz, F., \&Treyz, G. (2000). An Evolutionary New Economic Geography Model. Journal of Regional Science, 40(4), 671-695. doi:10.1111/0022-4146.00193

Fox, K. A., \& Krishna K. (1965). The functional economic area: Delineation and implications for economic analysis and policy. Papers of the Regional Science Association, 15(1), 57-85. doi:10.1007/bf01947866

Garson, D. (2013). Hierarchical linear modeling: guide and applications. Sage Publications

Ge, H., Canning, P., Goetz, S., Perez, A., \& Li, J. (2019). Embedding Economies of Scale Concepts in the Model of Optimal Locations of Fresh Produce Aggregation Hubs. Agricultural and Resource Economics Review, 48(3), $365-387$.

Goldstein, H. (2010). Multilevel Statistical Models. $4^{\text {th }}$ ed. Wiley

Ketokivi, M., Turkulainen, V., Seppälä, T., Rouvinen, P., \& Ali-Yrkkö, J. (2017). Why locate manufacturing in a high-cost country? A case study of 35 production location decisions. Journal of Operations Management, 49, 20-30.

King, L. J. (2020). Central Place Theory. Web Book of Regional Science. https://researchrepository.wvu.edu/rri-web-book/8

Lawson, B., Potter, A., Pil, F. K., \& Holweg, M. (2019). Supply chain disruptions: the influence of industry and geography on firm reaction speed. International Journal of Operations \& Production Management.

Leontief, W., \& Strout, A. (1963). Multiregional input-output analysis. In Structural interdependence and economic development (pp. 119-150). Palgrave Macmillan, London.

Lesh, A. (2007) Prostranstvennyaorgizaciyaxozyajstva [The spatial organization of economy]: Nauka

Liu, X., \& Hewings, G. J. (2019). Identification of changes in the economic interactions among sectors from 1995 to 2010 for Chicago economy using hierarchical feedback loop analysis. The Annals of Regional Science, 62(3), $637-655$.

Nystuen, J. D., \& Dacey, M. F. (1961). A graph theory interpretation of nodal regions. Papers of the Regional Science Association, 7(1), 29-42. doi:10.1007/bf01969070

Öner, Ö. (2016). Retail productivity: The effects of market size and regional hierarchy. Papers in Regional Science, 97(3), 711736. doi:10.1111/pirs.12268

Philbrick, A. K. (2005). Areal functional organization in regional geography. Papers in Regional Science, 3(1), 87-98. doi:10.1111/j.1435-5597.1957.tb01589.x

Quynh, M., Thu, T., Huong, Q., Van, A., Van, H., \& Van, D. (2020). Distribution center location selection using a novel multi criteria decision-making approach under interval neutrosophic complex sets. Decision Science Letters, 9(3), 501-510.

Sonis, M., Hewings, G. J. D., \& Gazel, R. (1995). The structure of multi-regional trade flows: hierarchy, feedbacks and spatial linkages. The Annals of Regional Science, 29(4), 409-430. doi:10.1007/bf01581885. 
1322

Timpf, S. (1997). Using Hierarchical Spatial Data Structures for Hierarchical Spatial Reasoning // Spatial Information Theory. A Theoretical Basis for GIS International Conference COSIT '97 Laurel Highlands. (Pennsylvania, USA. October 15-18), 69-84.

Webber, M. J. (2020). Industrial Location. Web Book of Regional Science, 9. https://researchrepository.wvu.edu/rri-web-book/9

Wicht, A., Kropp, P., \& Schwengler, B. (2019) Are functional regions more homogeneous than administrative regions? A test using hierarchical linear models. Papers in Regional Science ,1-30. https://doi.org/ 10.1111/pirs.12471

Yusupov, K.N., Timir'yanova, V.M., ToktamyshevaYu., S., \& Popov, D.V. (2018) Hierarchical and spatial effects in the development of municipalities. Economic and Social Changes: Facts, Trends, Forecast, 11(5), 137-154. doi: 10.15838/esc.2018.5.59.9

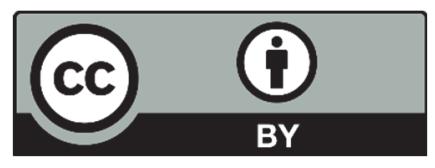

(C) 2020 by the authors; licensee Growing Science, Canada. This is an open access article distributed under the terms and conditions of the Creative Commons Attribution (CC-BY) license (http://creativecommons.org/licenses/by/4.0/). 